\title{
Dosage and pH optimization on stabilized landfill leachate via coagulation-flocculation process
}

\author{
Siti Nor Aishah Mohd-Salleh ${ }^{1, *}$, Nur Shaylinda Mohd-Zin ${ }^{1 *}$, Norzila Othman ${ }^{1}$, Nur \\ Syahirah Mohd-Amdan ${ }^{1}$, and Fitryaliah Mohd-Shahli ${ }^{1}$ \\ ${ }^{1}$ Faculty of Civil and Environmental Engineering, Universiti Tun Hussien Onn (UTHM), 86400 Parit \\ Raja, Johor, Malaysia
}

\begin{abstract}
Treatment on the generated landfill leachate is crucial as it can cause serious toxicological effects and environmental hazards, particularly when the unfavorable contaminants are left accumulated for a long period of time. The purpose of this study was to determine the optimum coagulant dosage of polyaluminium chloride (PAC) in selected dosage ranges (2250$4500 \mathrm{mg} / \mathrm{L}$ ) and to analyse the ideal $\mathrm{pH}$ of leachate sample (pH 3-10). PAC was tested on stabilized leachate taken from Simpang Renggam Landfill Site (SRLS), by investigating the percentage removals of five significant parameters, which were suspended solids, chemical oxygen demand (COD), ammonia, and heavy metals (iron (Fe) and chromium (Cr)). The removal efficiency was determined by a series of experiments using jar test. From the obtained results, it was found that $3750 \mathrm{mg} / \mathrm{L}$ and $\mathrm{pH} 7$ were the optimum conditions for PAC dosage and sample $\mathrm{pH}$, respectively. The conventional optimization test showed satisfactory results for suspended solids, $\mathrm{COD}, \mathrm{Fe}$, and $\mathrm{Cr}$ at $95 \%, 53 \%, 97 \%$, and $79 \%$ respectively, but had low removal on ammonia at $18 \%$. It can be concluded that the coagulationflocculation process has the potential to be applied as a primary treatment for stabilized landfill leachate in Malaysia.
\end{abstract}

\section{Introduction}

The age of landfill and long accumulation of contaminants will promote the degradation of organic matter present, thus influence the characteristics of leachate produced [1,2]. As the landfill get older, the activity of anaerobic decomposition in the site will reduce the biodegradable fraction of organic pollutants, thus cause stabilized leachate become higher polluted wastewater compare to the young ones [2]. The high accumulation of inorganic toxic compounds such as heavy metals and ammonia over a long period time are recognized as toxicants to the living organisms, which can cause further damaging consequences [3]. Typically, old leachate is harder to be treated. Stabilized leachates can be acknowledged through its $\mathrm{BOD}_{5} / \mathrm{COD}$ ratio that less than $<0.1$ [4]. This address that it is

\footnotetext{
*Corresponding author: nursha@uthm.edu.my, sitinoraishah.salleh@gmail.com
} 
important to carry out leachate characterization first to have a successful treatment strategy $[5,6]$.

Table 1. Summary of $\mathrm{BOD}_{5} / \mathrm{COD}$ corresponding to landfill age [4].

\begin{tabular}{|l|l|l|}
\hline BOD $5 /$ COD & Age of landfill & COD \\
\hline$\geq \mathbf{0 . 5}$ & Young $(<5$ year $)$ & $>10,000$ \\
\hline $\mathbf{0 . 1 - 0 . 5}$ & Medium $(5-10$ year $)$ & $500-10,000$ \\
\hline$<\mathbf{0 . 1}$ & Old $(>10$ year $)$ & $<500$ \\
\hline
\end{tabular}

Physical-chemical treatments like coagulation-flocculation method is suitable for stabilized leachate to remove the refractory substances, with high efficiencies depending on the type of coagulants [7]. Coagulation-flocculation is one of the applications that work efficiently on stabilized leachate, alongside the utilization of chemical coagulants. These parameters need to be controlled to come out with the satisfying and optimized impurities/contaminant reduction. Coagulation needs flocculation process to work efficiently. Coagulation by itself does not help much when the addition of coagulant may increase the insoluble compounds in treated sample, thus flocculation step is needed by allowing slow mixing key to obtain optimum performance [8]. In this study, the coagulant dosage and $\mathrm{pH}$ are selected to be the manipulated variables due to its dominance effect, while the temperature, jar test mixing speed, and settling time are controlled on their respective working conditions.

PAC has good structure of high charged density that gather much attention due to its non-limited optimum conditions $[9,10]$. Besides, low dosage applications showed excellent coagulant activity in previous reported studies [11-13]. PAC coagulants are claimed to be effective than other aluminium preparations particularly at low temperature or acidic $\mathrm{pH}$ for the coagulation of high turbidity waters [13]. The positively charged of $\mathrm{Al}(\mathrm{OH})$ precipitates help in adsorbing humic substances and improving flocculation kinetics [13]. As yet, there is no physicochemical method specialize in optimizing of coagulants doses by coagulation-flocculation, except using jar test. In particular, the combined coagulationflocculation process is adopted to eliminate suspended particles and insoluble substances, which is being a challenge for the removal of toxic heavy metals from leachates due to the mixed substances present [14].

\section{Study Area}

The study site is at Simpang Renggam landfill site (SRLS), located in Simpang Renggam, Kluang, Johor $\left(1^{\circ} 53^{\prime} 41^{\prime \prime N} 103^{\circ} 22^{\prime} 35^{\prime \prime} \mathrm{E}\right)$. The location of SRLS is about two kilometres away from Simpang Renggam town. The landfill has about six hectares in total size. The landfill receives 400-500 tonnes/day of wet solid wastes from three covered areas, which are Simpang Renggam, Kluang, and Batu Pahat.

Based on the physical observation and interviews, the available treatments in the landfill were still insufficient. Based on the preliminary data of leachate characterization, the landfill site alleged to generate stabilized leachate [15] which did not fit for biological treatment adoption. Thus, coagulation-flocculation was applied. 


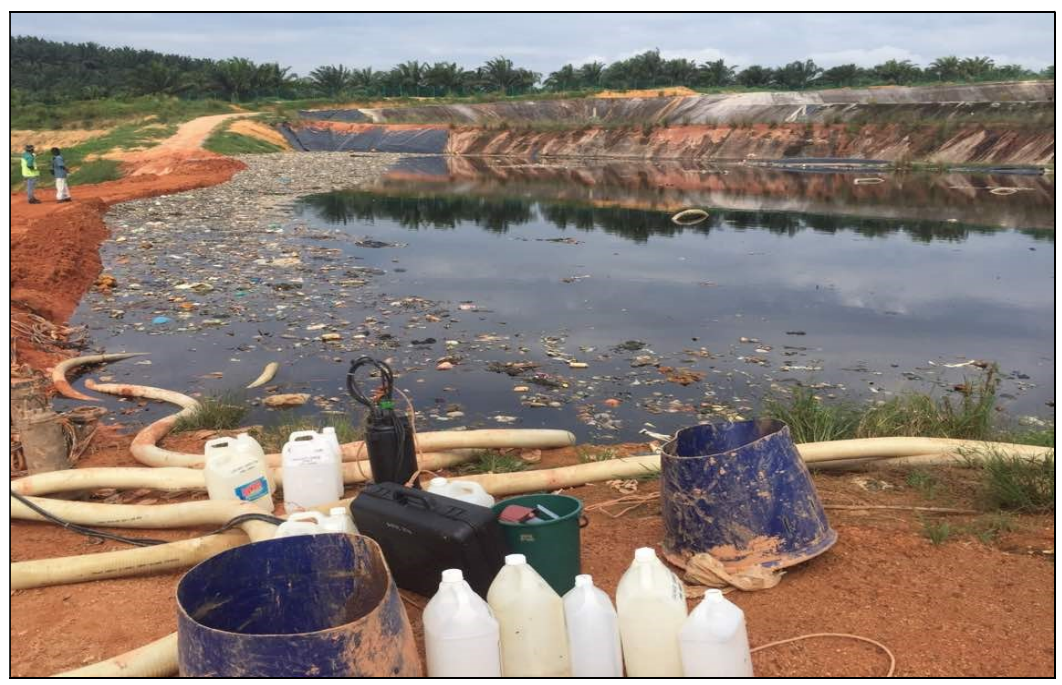

Fig. 1. Simpang Renggam Landfill Site (SRLS).

\section{Methodology}

\subsection{Leachate sampling}

The sampling point was located at the entrance of leachate pond. The sampling and storage of leachate samples were carried out according to APHA standard method. Samples of leachate influent was collected manually by grab sampling and immediately transferred into a cool room of $4^{\circ} \mathrm{C}$ at Waste Water Laboratory, Faculty of Civil and Environmental Engineering, Universiti Tun Hussien Onn Malaysia (UTHM). In the laboratory, the samples were tested as soon as possible for chemical oxygen demand (COD), biochemical oxygen demand (BOD), ammonia, suspended solids, and heavy metals ( $\mathrm{Fe}$ and $\mathrm{Cr}$ ). The characteristics of selected parameters are able to indicate the type and suitability of leachate for this study.

Table 2. Characteristic of leachate in January, 2018 from this study.

\begin{tabular}{|c|c|}
\hline Parameter & Average Value \\
\hline $\mathrm{pH}$ & 8.76 \\
\hline $\mathrm{COD}^{(\mathrm{mg} / \mathrm{L})}$ & 2954 \\
\hline BOD $_{5}(\mathrm{mg} / \mathrm{L})$ & 166.89 \\
\hline Ammonia $(\mathrm{mg} / \mathrm{L})$ & 920.4 \\
\hline Suspended solid $(\mathrm{mg} / \mathrm{L})$ & 275 \\
\hline $\mathrm{Fe}(\mathrm{mg} / \mathrm{L})$ & 7.61 \\
\hline $\mathrm{Cr}(\mathrm{mg} / \mathrm{L})$ & 0.56 \\
\hline $\mathrm{BOD}_{5} / \mathrm{COD}$ & 0.058 \\
\hline
\end{tabular}




\subsection{Preparation of coagulant}

PAC has a good structure of having higher charged density, been gather much attention due to its non-limited optimum conditions and low dosage utilization. It has been committed excellent coagulant activity in previous reported studies [9], [11]-[13], [16]. PAC coagulant is claimed to be effective than other aluminium preparations particularly at low temperature or acidic $\mathrm{pH}$ for the coagulation of high turbidity waters [13]. The positively charged of $\mathrm{Al}$ $(\mathrm{OH})$ precipitates help in adsorbing humic substances and improving flocculation kinetics [13]. According to the studies made by [12], the optimum $\mathrm{pH}$ for PAC is favourably higher than alum and showed efficient results in the view of physical-chemical treatment when tested on partially stabilized leachate, which also a highly polluted wastewater. Figure 2 shows the scanning electron microscopy (SEM) image of PAC in $10 \%$ stock solution at 600x magnification. The SEM analysis of PAC was done at the Environmental Analysis Laboratory, Faculty of Civil and Environmental Engineering, UTHM.

Commercial PAC was purchased from local laboratory supplier. The preparation of PAC stock solution was prepared according to [16], [19]. 10 grams of PAC was weighed and diluted in $100 \mathrm{ml}$ of distilled water, to produce $10 \%$ concentration of stock solution coagulant. The stock solution was prepared on the same day as the experiment jar test experiment.

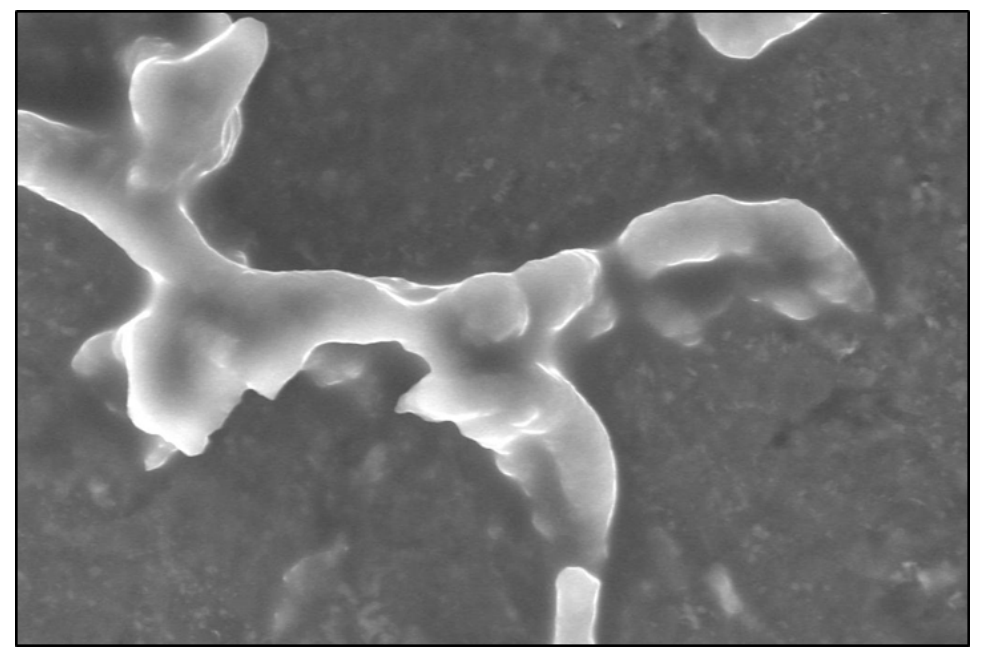

Fig. 2. SEM image of PAC in 10\% stock solution at 600x magnification.

\subsection{Working conditions (Jar test, coagulant dosage, $\mathrm{pH}$ )}

All working conditions in this study were done by following the methodology of [17], as in Table 3 that shows the ranges of operating parameters for coagulation-flocculation test. The working conditions of jar test were applied to obtain the respective optimum $\mathrm{pH}$ of leachate sample and PAC dosage. The performance of coagulant in this study was compared with other utilizations of PAC in past studies in order to collate its efficiency. The obtained results were analysed using Excel to obtain the optimum value using graph; this procedure is also known as the conventional optimization method.

A coagulation process consists of three distinct steps. Firstly, the PAC coagulant was added to the sample with a determined $\mathrm{pH}$ value of leachate, before rapid mixings was initiated. The aim was to obtain a complete mixing of the coagulant with the leachate sample in order to maximize the effectiveness of the destabilization of colloidal particles. 
Next, the suspension was slowly stirred to increase contact between the coagulation particles and to initiate the development of large floc in the flocculation process. Third, the mixing was stopped and the flocs was allowed to settle. After that, supernatant was collected three centimetre $(\mathrm{cm})$ from the surface by using a plastic syringe for analytical measurement. The collected leachate sample was analysed to obtain the optimum conditions based on $\mathrm{COD}$, suspended solids, ammonia, $\mathrm{Fe}$, and $\mathrm{Cr}$ removals (standard method listed in Table 4). The removal efficiency of COD, suspended solids, ammonia, Fe, and $\mathrm{Cr}$ were calculated based on the equation below;

Percentage removal $(\%)=[$ Initial concentration - Final concentration $] \times 100$

$$
\text { [Initial concentration] }
$$

Table 3. Ranges of operating parameters for coagulation-flocculation test.

\begin{tabular}{|l|c|}
\hline \multicolumn{1}{|c|}{ Parameter } & Working condition \\
\hline Speed of rapid mixing (rpm) & 200 \\
\hline Duration of rapid mixing (min) & 4 \\
\hline Speed of slow mixing (rpm) & 30 \\
\hline Duration of slow mixing (min) & 15 \\
\hline Settling time (min) & 30 \\
\hline Temperature $\left({ }^{\circ} \mathrm{C}\right)$ & $3-10$ \\
\hline $\mathrm{pH}$ & Room temperature $\left(20-25^{\circ} \mathrm{C}\right)$ \\
\hline Dosage & $2250-4500 \mathrm{mg} / \mathrm{L}$ \\
\hline
\end{tabular}

Table 4. List of used standard methods in this study according to Standard Methods for Water and Wastewater (APHA).

\begin{tabular}{|l|c|}
\hline \multicolumn{1}{|c|}{ Parameter } & Methods \\
\hline Chemical oxygen demand (COD) & APHA Method: 5220 C \\
& HACH Method:8000 \\
\hline Suspended solids & APHA Method:2540 D \\
& HACH Method:630 \\
\hline Ammonia & HACH Method: 8038 \\
\hline $\mathrm{Fe}$ and $\mathrm{Cr}$ & APHA Method:3120 \\
\hline
\end{tabular}

\section{Result and Discussion}

\subsection{Optimization of coagulation-flocculation}

Determination of optimum condition for coagulation-flocculation using selected variables was taken place by using conventional method of 'change one factor at a time', which involved the trial and error practices [17]. Specifically, the coagulant dosage and $\mathrm{pH}$ were the considered factors in this study. By using this method, $\mathrm{pH}$ factor was fixed at 7 while coagulant dosage range was between $2250 \mathrm{mg} / \mathrm{L}, 2500 \mathrm{mg} / \mathrm{L}, 2750 \mathrm{mg} / \mathrm{L}, 3000 \mathrm{mg} / \mathrm{L}, 3250$ $\mathrm{mg} / \mathrm{L}, 3500 \mathrm{mg} / \mathrm{L}, 3750 \mathrm{mg} / \mathrm{L}, 4000 \mathrm{mg} / \mathrm{L}, 4250 \mathrm{mg} / \mathrm{L}$, and $4500 \mathrm{mg} / \mathrm{L}$, respectively. The optimum coagulant dosage was determined by the highest removal percentages on chemical oxygen demand (COD), suspended solids, ammonia, iron (Fe), and Chromium (Cr). Next, by using the optimum and constant coagulant dosage, the $\mathrm{pH}$ range was varied from 3 to 10 to decide the ideal conditions for leachate sample. The $\mathrm{pH}$ of leachate sample then was altered to $\mathrm{pH} 7$ by using $1 \mathrm{~N}$ hydrocloric acid. 
Based on the observation on the Figure 3 (a) the removal percentages on suspended solids and $\mathrm{Fe}$ were continuously increasing from dosage 2250 to $4500 \mathrm{mg} / \mathrm{L}$. However for $\mathrm{Cr}$, the removal percentages decreased at dosage of $4500 \mathrm{mg} / \mathrm{L}$. While the removal percentages for other parameters were bit fluctuating at the initial and final dosage ranges. From the outcome results, the removal percentages for COD and ammonia were the lowest compared to others. The removals were lower might due to its chemical characteristics that did not counterpart much with coagulation-flocculation process. Nonetheless, the removal percentages for suspended solids, $\mathrm{Fe}$, and $\mathrm{Cr}$ were quite satisfying. Through this first step of optimization process, it was noticed that the optimum coagulation-flocculation occured at $3750 \mathrm{mg} / \mathrm{L}$ with $96 \%, 44 \%, 52 \%, 96 \%$, and $66 \%$ for suspended solids, ammonia, COD, Fe, and $\mathrm{Cr}$ respectively. In order to comfirm the optimum coagulation-flocculation process of single PAC dosage at $3750 \mathrm{mg} / \mathrm{L}$, the second jar test was carried out with the same conditions.

Based on the second jar test in optimizing the single PAC dosage (Figure 3 (b)), the results showed better removal percentages for parameter $\mathrm{COD}$ and $\mathrm{Cr}$ compared to the previous one. Overall, through Figure 3 (b), the graph showed the removal percentages were increasing gradually without much fluctuating like in experiment 1 , with all the applied PAC dosages. Nevertheless, after the application of $3750 \mathrm{mg} / \mathrm{L} \mathrm{PAC}$ dosage, the removal percentages of most paramaters were decreasing, such as SS, AN, and COD. While the after treatment affect decreased at $4500 \mathrm{mg} / \mathrm{L}$ for the removal heavy metal Cr. The removal of Fe after treatment indicated continuous removal even though at dosage 4500 $\mathrm{mg} / \mathrm{L}$, which showed the same trend in the first jar test (Figure 3 (a)). As a whole, the second carried out jar test showed the optimum single PAC dosage occured at $3750 \mathrm{mg} / \mathrm{L}$ as well, with removal percentages of $94,17,70.32,96.94$, and $83.12 \%$ for SS, AN, COD, $\mathrm{Fe}$, and $\mathrm{Cr}$ respectively. Since the optimum coagulant dosage of single PAC was achieved, the conventional optimization was continued with varied $\mathrm{pH}$ of leachate samples. The results for third jar test were presented as in Figure 3 (c).

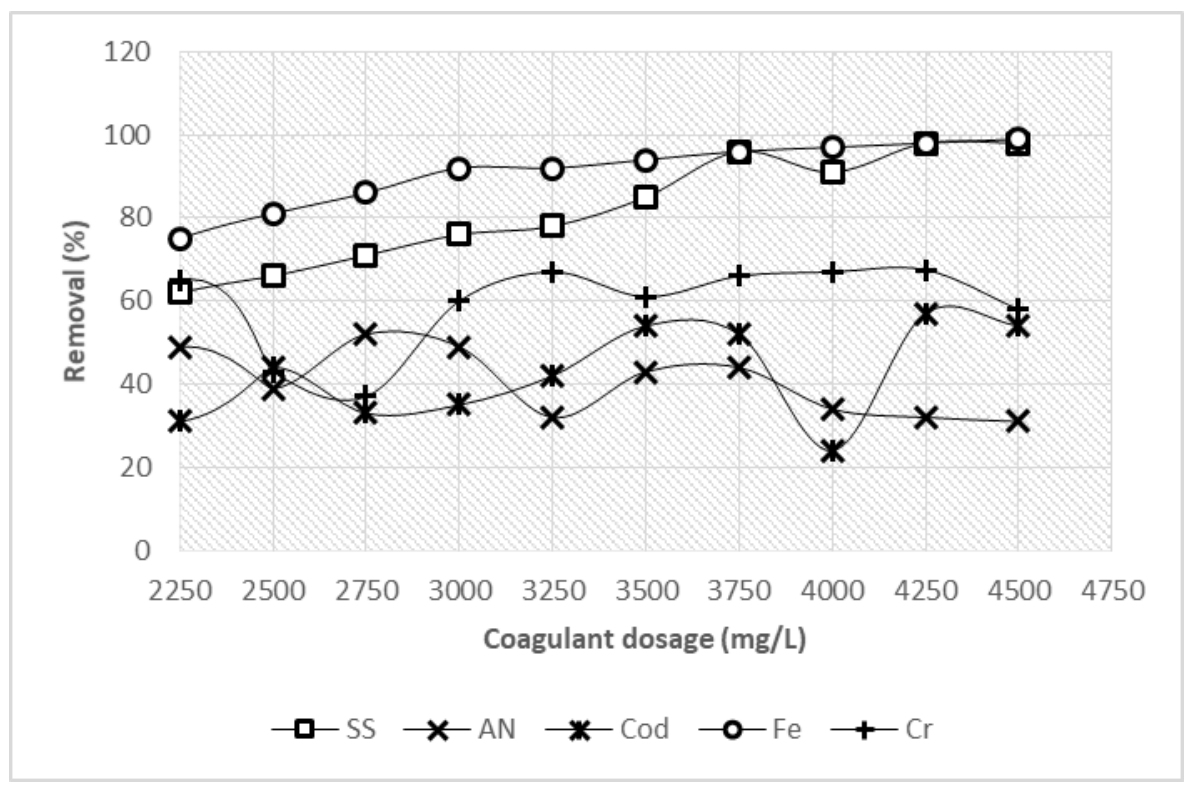

(a) 


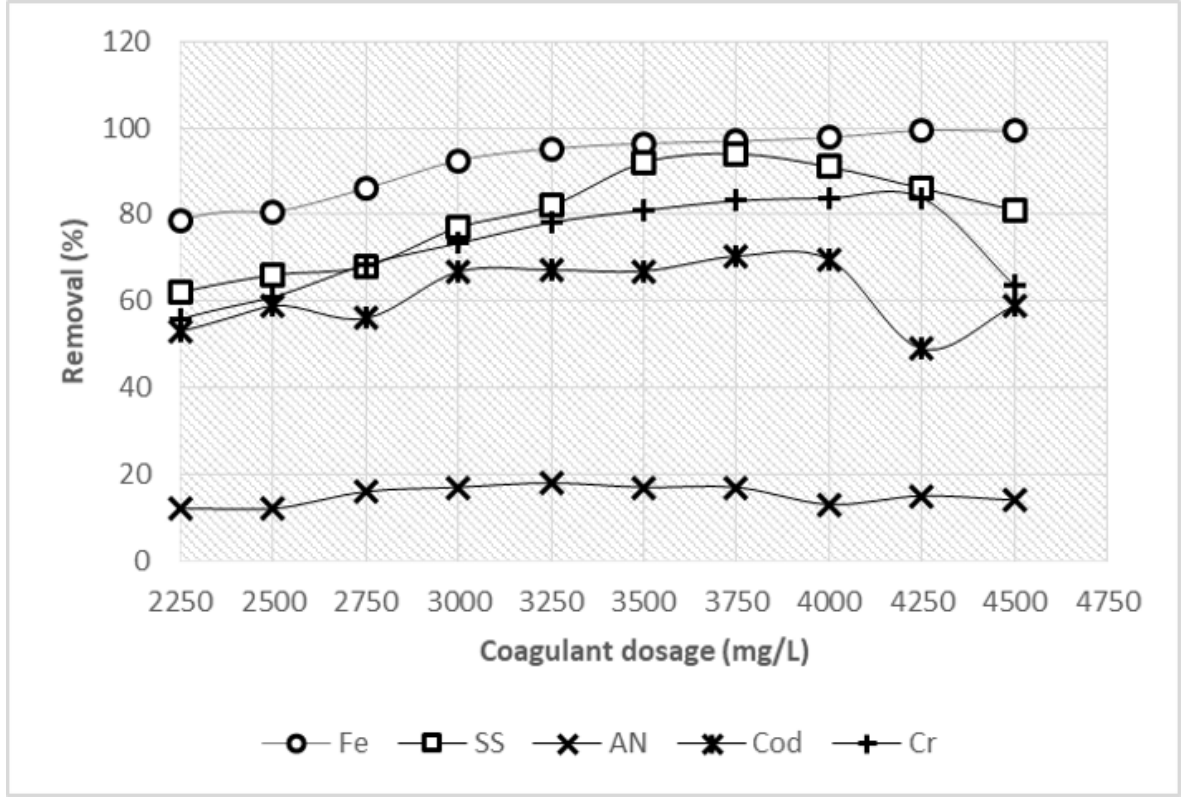

(b)

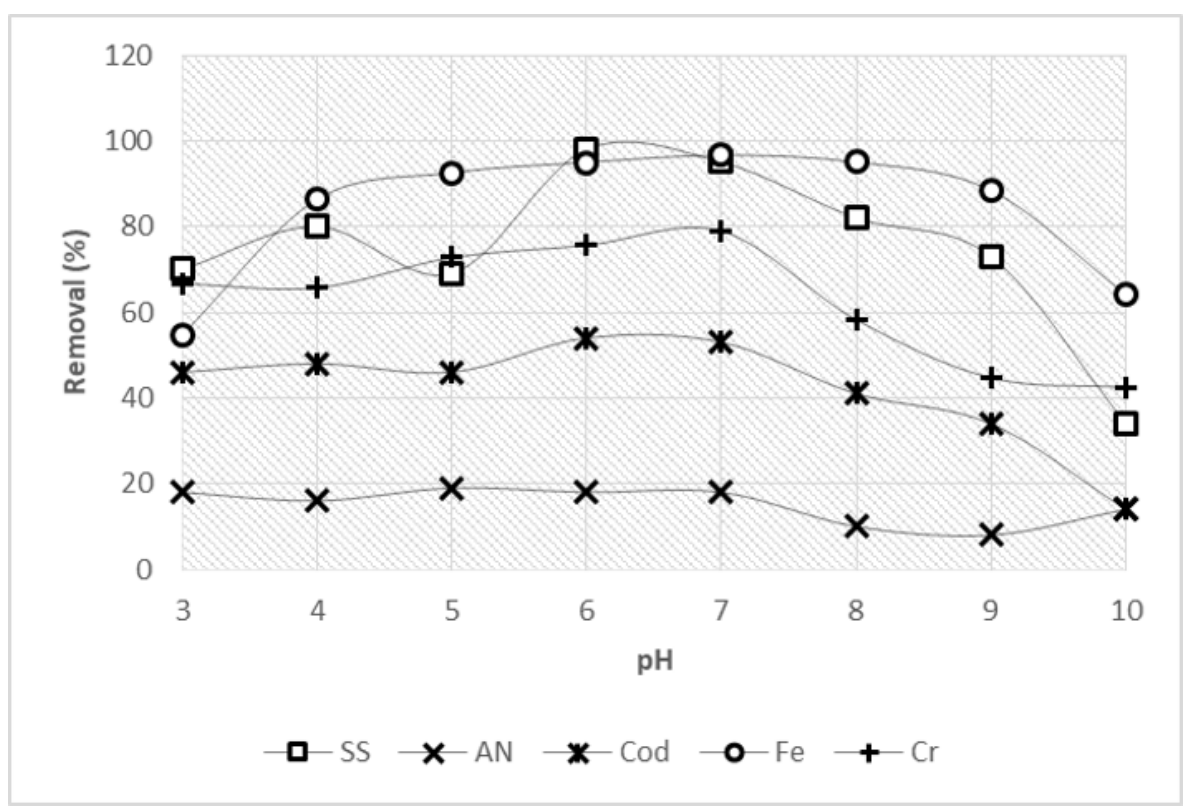

(c)

Fig. 3.:(a) Single PAC coagulant at $\mathrm{pH} 7$ with varied $\mathrm{pH} 2250-4500 \mathrm{mg} / \mathrm{L}$ (b) Second repetition of single PAC coagulant at $\mathrm{pH} 7$ with varied dosage $2250-4500 \mathrm{mg} / \mathrm{L}$ (c) Single optimum PAC coagulant at $3750 \mathrm{mg} / \mathrm{L}$ with varied $\mathrm{pH} 3-10$.

The $\mathrm{pH}$ of leachate samples were altered using $1 \mathrm{~N}$ of hydrocloric acid and sodium hydroxide, from $\mathrm{pH} 3$ to $\mathrm{pH} 10$. Based on Figure 3 (c), the removal percentages of most 
parameters showed increasing trends from $\mathrm{pH} 3$ to 6 , but decrease at $\mathrm{pH} 7$ to 10 . However, for centain parameters, the significant removal percentages were recorded at different $\mathrm{pH}$ values. Individually, the highest removal for each parameter was $98 \%$ for suspended solids at $\mathrm{pH} 6,19 \%$ for ammonia at $\mathrm{pH} 5,54 \%$ for $\mathrm{COD}$ at $\mathrm{pH} 6,97 \%$ for $\mathrm{Fe}$ at $\mathrm{pH} 7$, and $79 \%$ for $\mathrm{Cr}$ at $\mathrm{pH}$ 7. In the third-repeated jar test, the removal percentages of $3750 \mathrm{mg} / \mathrm{L}$ dosage of PAC at both pH 6 and 7 had almost approximate outcomes. At $\mathrm{pH} 6$, the gained results was $98 \%, 18 \% 54 \%, 95 \%$, and $76 \%$, meanwhile its $95 \%, 18 \%, 53 \%, 97 \%$, and $79 \%$ at $\mathrm{pH} 7$, consecutively resembling for suspended solids, ammonia, $\mathrm{COD}, \mathrm{Fe}$, and $\mathrm{Cr}$ parameters. Therefore it showed that based on the removal percentages at both $\mathrm{pH}$ values, $\mathrm{pH} 6$ and 7 had the same dominance, with the difference was not more than $5 \%$ each. Since the average $\mathrm{pH}$ value of raw leachate in this study was $8.76, \mathrm{pH} 7$ was chosen as the optimum $\mathrm{pH}$ condition in this study of single PAC coagulant. It was considered at $\mathrm{pH} 7$ due to the less used volume of hydrochloric acid in altering the $\mathrm{pH}$ of leachate sample. Nevertheless, it was also considered due to the required 'real-life' application on site, which neutral $\mathrm{pH}$ is prioritized [19]. The result in this study was compared with the application of PAC coagulant from previous literature reviews. Table 5 shows the utilization comparison of PAC coagulant on leachate sample with previous studies.

Table 5. Utilization comparison of polyaluminium chloride (PAC) coagulant on leachate sample with previous studies.

\begin{tabular}{|c|c|c|c|}
\hline $\begin{array}{c}\text { Optimum dosage } \\
(\mathrm{mg} / \mathrm{L})\end{array}$ & Optimum pH & $\begin{array}{c}\text { Removal parameter } \\
(\%)\end{array}$ & Reference \\
\hline 3750 & pH 7 & $\begin{array}{c}\text { Suspended solids }(95 \%) \\
\text { Ammonia }(18 \%) \\
\text { COD }(53 \%) \\
\operatorname{Fe}(97 \%) \\
\operatorname{Cr}(79 \%)\end{array}$ & $\begin{array}{c}\text { From this } \\
\text { study }\end{array}$ \\
\hline 2500 & pH 7 & $\begin{array}{c}\text { Suspended solids }(92 \%) \\
\text { Turbidity }(77 \%) \\
\text { Colour }(94 \%) \\
\text { COD }(37 \%) \\
\text { Ammonia }(32 \%)\end{array}$ & [19] \\
\hline 2000 & pH 7 & $\begin{array}{c}\text { COD (49\%) } \\
\text { Ammonia (29\%) }\end{array}$ & [20] \\
\hline 7200 & pH 6 & $\begin{array}{c}\text { COD }(55 \%) \\
\text { Colour }(80 \%) \\
\text { Suspended solids }(95 \%)\end{array}$ & [21] \\
\hline 1900 & pH 7 & $\begin{array}{c}\text { COD }(57 \%) \\
\text { Colour }(97 \%) \\
\text { Suspended solids }(97 \%) \\
\text { Turbidity }(99 \%)\end{array}$ & [12] \\
\hline
\end{tabular}

In the coagulation-flocculation process using single $\mathrm{PAC}$ coagulant, optimization at $\mathrm{pH}$ 7 seems general, according to [12], [19-21]. In this study, it was found that $3750 \mathrm{mg} / \mathrm{L}$ dosage of PAC works well with $\mathrm{pH} 7$, which proven through the first and third jar tests. At certain parameter, the removals were found to be higher at the first jar test, such as suspended solid and ammonia at $96 \%$ rather than $95 \%$, and $44 \%$ rather than $18 \%$, consequtively. Meanwhile, for parameter $\mathrm{Cr}$, the removal at third jar test was higher, which 
at $79 \%$ rather than $66 \%$. Based on the observations, the obvious difference values could be seen in parameter of ammonia and chromium. Generally, through comparison with the previous studies, the removal of ammonia was usually low, especially when coagulationflocculation process was used [20]. The ammonia concentration in the leachate sample used in the first jar test might be lesser than the leachate sample used in the third jar test, which cause higher removal than the last one. As eloquently stated by [6], the ammonia nitrogen content loads in the leachates are toxicants and may become the eradicate factor to physical-chemical treatment method. Thus, the pre-treatment to get rid ammonia pollutants first is such a crucial step, for instance, by integrating biological practices [22]. Moreover, the leachate in SRLS nowadays has become more high-strength, due to the dosage comparison from previous study [19], that used the same source of leachate sample taken from SRLS. Logically, if higher pollutants are present, higher dosage is required as well.

\section{Conclusion}

Hence, in a conclusion, the optimization of single PAC dosage occurs at $3750 \mathrm{mg} / \mathrm{L}$ dosage and $\mathrm{pH} 7$ with the results of removal percentages at satisfying outcomes, at $95 \%, 18 \%$, $53 \%, 97 \%$, and $79 \%$ for suspended solids, ammonia, COD, Fe, and $\mathrm{Cr}$ respectively. it is recommended to reduce the dosage of PAC coagulant or any other chemical coagulants that are frequently used in the wastewater treatment for future research and studies. This is due to, despite the superiority of of these chemical coagulants, they also have negative sides by referring to the past literature [23]-[28][23]-[27], [29], such as hazards on living organisms and human health [26], [27], [30], [31]. Sustainability treatments are preferable when talking about forthcoming-next green remediation. Therefore, by studying on new sustainable coagulants, these drawbacks at least can be tackled if not entirely, just to lessen the flaw is already a pleased advancement.

This work was supported by Universiti Tun Hussein Onn Malaysia under FRGS grant scheme FRGS Vot 1570. The authors also wish to acknowledge Majlis Perbandaran Kluang and SWCorp for their assistance during the sampling process.

\section{References}

1. F. A. El-Gohary and G. Kamel, "Characterization and biological treatment of pretreated landfill leachate," Ecol. Eng., vol. 94, pp. 268-274, 2016.

2. S. Q. Aziz, H. A. Aziz, M. J. K. Bashir, and A. Mojiri, "Assessment of Various Tropical Municipal Landfill Leachate Characteristics and Treatment Opportunities," Glob. NEST J., vol. 17, no. 3, pp. 439-450, 2015.

3. N. Rusdizal, H. A. Aziz, and F. Mohd Omar, "Potential use of polyaluminium chloride and tobacco leaf as coagulant and coagulant aid in post-treatment of landfill leachate," Avicenna J Environ. Heal. Eng. Press, pp. 1-5, 2015.

4. B. P. Naveen, S. Puvvadi, and T. G. Sitharam, "Characteristics of a Municipal Solid Waste Landfill," Proc. Indian Geotech. Conf. IGC-2014, no. December 18-20, pp. 1-7, 2014.

5. F. Kargi and M. Y. Pamukoglu, "Adsorbent supplemented biological treatment of pretreated landfill leachate by fed-batch operation," Bioresour. Technol., vol. 94, no. 3, pp. 285-291, 2004.

6. N. S. Mohd Zin, H. Abdul Aziz, M. N. Adlan, and A. Ariffin, "Characterization of leachate at Matang Landfill," Acad. J. Sci., vol. 1, no. 2, pp. 317-322, 2012. 
7. M. Verma and R. Naresh Kumar, "Can coagulation-flocculation be an effective pretreatment option for landfill leachate and municipal wastewater co-treatment?," Perspect. Sci., vol. 8, pp. 492-494, 2016.

8. M. Al-Sameraiy, "A Novel Water Pretreatment Approach for Turbidity Removal Using Date Seeds and Pollen Sheath," J. Water Resour. Prot., vol. 04, no. 02, pp. 79-92, 2012.

9. S. Y. Choy, K. M. N. Prasad, T. Y. Wu, M. E. Raghunandan, and R. N. Ramanan, "Utilization of plant-based natural coagulants as future alternatives towards sustainable water clarification," J. Environ. Sci. (China), vol. 26, no. 11, pp. 2178-2189, 2014.

10. F. Ni, X. Peng, J. He, L. Yu, J. Zhao, and Z. Luan, "Preparation and characterization of composite bioflocculants in comparison with dual-coagulants for the treatment of kaolin suspension," Chem. Eng. J., vol. 213, pp. 195-202, 2012.

11. N. A. Zainol, H. A. Aziz, M. S. Yusoff, and M. Umar, "The use of Polyaluminum Chloride for the treatment of Landfill Leachate via Coagulation and Flocculation processes," Res. J. Chem. Sci., vol. 1, no. 3, pp. 34-39, 2011.

12. S. Ghafari, H. A. Aziz, and M. J. K. Bashir, "The use of poly-aluminum chloride and alum for the treatment of partially stabilized leachate: A comparative study," Desalination, vol. 257, no. 1-3, pp. 110-116, 2010.

13. Y. H. Shen and B. A. Dempsey, "Synthesis and speciation of polyaluminum chloride for water treatment," Environ. Int., vol. 24, no. 8, pp. 899-910, 1998.

14. E. A. López-Maldonado, M. T. Oropeza-Guzman, J. L. Jurado-Baizaval, and A. OchoaTerán, "Coagulation-flocculation mechanisms in wastewater treatment plants through zeta potential measurements," J. Hazard. Mater., vol. 279, pp. 1-10, 2014.

15. L. W. M. Zailani, N. S. M. Amdan, and N. S. M. Zin, "Characterization of Leachate at Simpang Renggam Landfill Site, Johor, Malaysia," IOP Conf. Ser. Earth Environ. Sci., vol. 140, no. 1, p. 012053, 2018.

16. F. Ni, J. He, Y. Wang, and Z. Luan, "Preparation and characterization of a cost-effective red mud/polyaluminum chloride composite coagulant for enhanced phosphate removal from aqueous solutions," J. Water Process Eng., vol. 6, pp. 158-165, 2015.

17. N. S. Mohd-Zin, H. A. Aziz, M. N. Adlan, A. Ariffin, M. S. Yusoff, and I. Dahlan, "Treatability Study of Partially Stabilized Leachate by Composite Coagulant (Prehydrolyzed Iron and Tapioca Flour )," Int. J. Sci. Res. Knowl., vol. 2, no. 7, pp. 313-319, 2014.

18. K. P. Y. Shak and T. Y. Wu, "Optimized use of alum together with unmodified Cassia obtusifolia seed gum as a coagulant aid in treatment of palm oil mill effluent under natural pH of wastewater," Ind. Crops Prod., vol. 76, pp. 1169-1178, 2015.

19. O. Mohamad Azizan, "Treatment of Leachate By Coagulation and Flocculation Process using A Novel Composite Coagulant Made from Polyaluminum Chloride (Pac) and Tapioca Starch (Ts) in Removing Cod, Ammonia, Colour and Suspended Solid From Stabilized Leachate" Master Thesis, no. October, 2018.

20. L. M. Rui, Z. Daud, A. Aziz, and A. Latif, "Coagulation-Flocculation In Leachate Treatment Using Combination Of PAC With Cationic And Anionic Polymers," Int. J. Eng. Res. Appl., vol. 2, no. August, pp. 1935-1940, 2012.

21. Y. A. J. Al-Hamadani, M. S. Yusoff, M. Umar, M. J. K. Bashir, and M. N. Adlan, "Application of psyllium husk as coagulant and coagulant aid in semi-aerobic landfill leachate treatment," J. Hazard. Mater., vol. 190, no. 1-3, pp. 582-587, 2011.

22. N. S. Mohd-Zin, H. A. Aziz, N. M. Adlan, A. Ariffin, M. S. Mohd Suffian, and I. Dahalan, "Removal of Color, Suspended Solids, COD and Ammonia from Partially 
Stabilize Landfill Leachate by Using Iron Chloride through Coagulation Process," Int. J. Eng. Technol., vol. 5, no. 6, pp. 736-739, 2013.

23. F. K. Amagloh and A. Benang, "Effectiveness of Moringa Oleifera Seed as Coagulant for Water Purification," African J. Agric. Res., vol. 4, no. 2, pp. 119-123, 2009.

24. A. H. Birima, H. A. Hammad, M. N. M. Desa, and Z. C. Muda, "Extraction of natural coagulant from peanut seeds for treatment of turbid water," IOP Conf. Ser. Earth Environ. Sci., vol. 16, pp. 1-4, 2013.

25. J. Debora, P. Theodoro, G. F. Lenz, R. F. Zara, and R. Bergamasco, "Coagulants and Natural Polymers : Perspectives for the Treatment of Water," Plast. Polym. Technol., vol. 2, no. 3, pp. 55-62, 2013.

26. J. Saravanan, D. Priyadharshini, A. Soundammal, G. Sudha, and K. Suriyakala, "Wastewater Treatment using Natural Coagulants," SSRG Int. J. Civ. Eng., vol. 4, no. 3, pp. 40-42, 2017.

27. W. Subramonian, T. Y. Wu, and S. P. Chai, "A comprehensive study on coagulant performance and floc characterization of natural Cassia obtusifolia seed gum in treatment of raw pulp and paper mill effluent," Ind. Crops Prod., vol. 61, pp. 317-324, 2014.

28. F. P. Camacho, V. S. Sousa, R. Bergamasco, and M. Ribau Teixeira, "The use of Moringa oleifera as a natural coagulant in surface water treatment," Chem. Eng. J., vol. 313, pp. 226-237, 2017.

29. M. R. Teixeira, F. P. Camacho, V. S. Sousa, and R. Bergamasco, "Green technologies for cyanobacteria and natural organic matter water treatment using natural based products," J. Clean. Prod., vol. 162, pp. 484-490, 2017.

30. B. Y. Gao, Q. Y. Yue, and Y. Wang, "Coagulation performance of polyaluminum silicate chloride (PASiC) for water and wastewater treatment," Sep. Purif. Technol., vol. 56, no. 2, pp. 225-230, 2007.

31. M. A. Rasool, B. Tavakoli, N. Chaibakhsh, A. R. Pendashteh, and A. S. Mirroshandel, "Use of a plant-based coagulant in coagulation-ozonation combined treatment of leachate from a waste dumping site," Ecol. Eng., vol. 90, pp. 431-437, 2016.

32. B. Y. Gao, Y. Wang, Q. Y. Yue, J. C. Wei, and Q. Li, "Color removal from simulated dye water and actual textile wastewater using a composite coagulant prepared by ployferric chloride and polydimethyldiallylammonium chloride," Sep. Purif. Technol., vol. 54, no. 2, pp. 157-163, 2007. 